\title{
Feminist Art Criticism: Issues in Feminist Criticism Written about the Work of May Stevens
}

\section{Elizabeth Garber}

\section{Defining Feminist Art Criticism}

When I first became aware of so-called "Second-Wave Feminism," it was 1968 (The First-Wave was the Suffragette Movement during the early years of this century). A group of women demonstrators staged "The Burial of Traditional Womanhood," a torchlight parade at Arlington Cemetery. The action can be remembered as symbol for the essentially political nature of feminism. Political advocacy and activism characterize all aspects of the feminist movement, including art and art criticism.

In using the term feminist art criticism, I refer to a set of critical perspectives on art or on women in art that, as Suzanne Lacy has written, "show a consciousness of women's social and economic position in the world" (cited in Roth, 1980, p. 37) or that reflect a woman's consciousness about women. Feminist criticism is a political act, meant as a challenge to women's oppression, a "cultural intervention" (Kuhn, 1982, p. 8) into the "structural, economic, political and ideological critiques of the power relations of society" (Pollock, 1987, p. 93).

The subject woman/women has undergone a conceptual change during the last decade, reflected in feminist art critics' definition of their subject. While mainstream feminist critics of the 1970s discussed "woman" as having universally shared qualities which differentiated her from "man," beginning in the 1980s, recognition and appreciation of differences between women and their experiences supplanted the focus on similarities. We often read and hear today "gender, race, class, ethnicity, sexual preference, and ableness" among other distinctions which differentiate (and stereotype and oppress) women.

I emphasize "there is no single authoritative or basic feminist criticism against which others can be measured" (Garber, 1989, p. 3). But there exist shared premises and goals. That women have been misrepresented in art and marginalized from positions of power in the art world, that these conditions continue in 1990 (1) and that they must change are premises and goals generally accepted by most feminist critics. How feminist critics envision attaining their goal is reflected below.

Working Papers in Art Education 1989 - 1990 


\section{Bases and Strands of Feminist Art Criticism}

Not long after the bra burning in 1968, "consciousness-raising" became widely associated with feminism. Adopted from the writings of Karl Marx, consciousness-raising was initiated by a group known as the New York Radical Women. It was seen as a preliminary step to social revolution. By gathering the thoughts and experiences of women, a class consciousness in the oppressed (women) could be formed in dialectic opposition to the ideologies of the ruling class (men). Consciousness-raising brought knowledge about women's experiences and subjectivity to the fore as a political strategy towards changing the extant ("patriarchal") perception and roles of women in society.

In 1971, Linda Nochlin published her seminal article "Why Are There No Great Women Artists?" (2) "The fault lies not in our stars, our hormones, our menstrual cycles, or our empty internal spaces, but in our institutions and our education," she concluded (p. 483). In her analysis of women's exclusion from art, she traced their education and social definitions as limiting factors. In this respect, Nochlin presaged current feminist art criticism which utilizes neo-Marxist, semiological, post-structuralist, and psychoanalytic methods to analyze the social construction of women.

These three examples: the torchlight parade, consciousness-raising, and Nochlin's article form bases for contemporary "mainstream" feminist art criticism. (3) Feminist art criticism is a political act, allows for the development of a consciousness about women based on their experiences and subjectivity, and seeks to clarify and undermine the role of social institutions in defining women. Feminist criticism should not be understood, however, as a singular approach to interpreting art. While the goals of feminist critics are equal opportunity, recognition of women's voices and experiences as valid and important, and fundamental changes in the social, political, economic, cultural, aesthetic, and belief structures which cause men and women to be treated differently, the bases named above reify as three different strands of feminist art criticism, in which each characteristic or basis becomes a strategy towards achieving the goals of the feminist movement.

The political basis of feminism takes form in what I shall call activist criticism, the basis of consciousness about women as woman-centered criticism, and social analysis as analytical criticism. Activist feminist art critics emphasize the ways in which feminist art acts against women's oppression. Activist critics report the political content of feminist art and champion its political causes. For woman-centered feminist critics, the discovery and construction of bonds between women and a building of women's community is celebrated. Analytic feminist critics concentrate on exposing, analyzing, and undermining social and cultural forces that oppress women. Womancentered and analytic feminist critics are, of course, political acts. It is the object of criticism which differs in each of these strands. Political acts are the taproot of activist feminist criticism, women's experiences and bonds the 
nucleus of woman-centered criticism, and social systems the focus of analytic feminist art criticism.

\section{Feminist Art Criticism and May Stevens' Ordinary. Extraordinary}

These three strands can be examined through study of feminist criticism written about May Stevens' Ordinary. Extraordinary. In this ongoing series of collages, xerography, and paintings which she began in 1976, Stevens juxtaposes Rosa Luxemburg, a Polish/German revolutionary leader and socialist theoretician, and Alice Dick Stevens, the artist's mother, a housewife who became mute and spent years institutionalized for mental problems. The series "examine[s] and document[s] the mark of a political woman and mark[s] the life of a woman whose life would otherwise be unmarked" (Stevens, 1980, n.p.). Individual works in the series may combine Rosa and Alice (4) or may depict them separately. May Stevens is a feminist and socialist herself; much of her work over the past three decades has been political. She writes and speaks eloquently of these commitments and of her work. The feminist readings of her work even so vary, underscoring the variety of approaches to change that feminist art critics embrace.

Critic Carol Jacobsen (1989) presents an example of activist feminist art criticism in writing about Ordinary. Extraordinary. She is interested in Stevens as a political and feminist artist working towards social change through political and feminist systems. She begins by claiming. "the feminist perspective of May Stevens's art. . came out of her participation in the politics of the Left" (p. 153). She traces the artist's earlier political art made in response to civil rights issues, the Vietnam War, and patriarchal dominance. The critic acknowledges personal content in Stevens' work (the image of the artist's mother), but contextualizes it within the political: "her vision is always infused with socialist politics" (p. 154). She understands Stevens as intervening in the silence of women such as Alice by portraying her as a worthy subject of art. Through the artist, Jacobsen argues, Alice damns traps that bar women from the public sphere. In using Rosa and Alice, "Stevens hoped to implement the socialist strategy of integrating theory with practice by beginning with real individuals" (p. 154).

Jacobsen understands Stevens' choices of media and imagery as decisions based on the communicative impact of the political message. Photographs are repeated, reversed from positive to negative, and employ scale juxtapositions, overlays, and transparencies. Different media are combined. These techniques, explains Jacobsen, form disjunctions which are representative of the permanent revolution of the Left. The spontaneity and expressionism evident in the way large painted canvases such as Voices were painted echo "protest marches, [that] literally and formally refer to 'movement,' and ... also recall the political assassinations of our own times" (p. 183). Jacobsen argues the juxtaposition of these images not simply in an 
historical context: "by collaging them with contemporary feminist analysis, Stevens aims the new composite at our awareness of the world today" (p. 185).

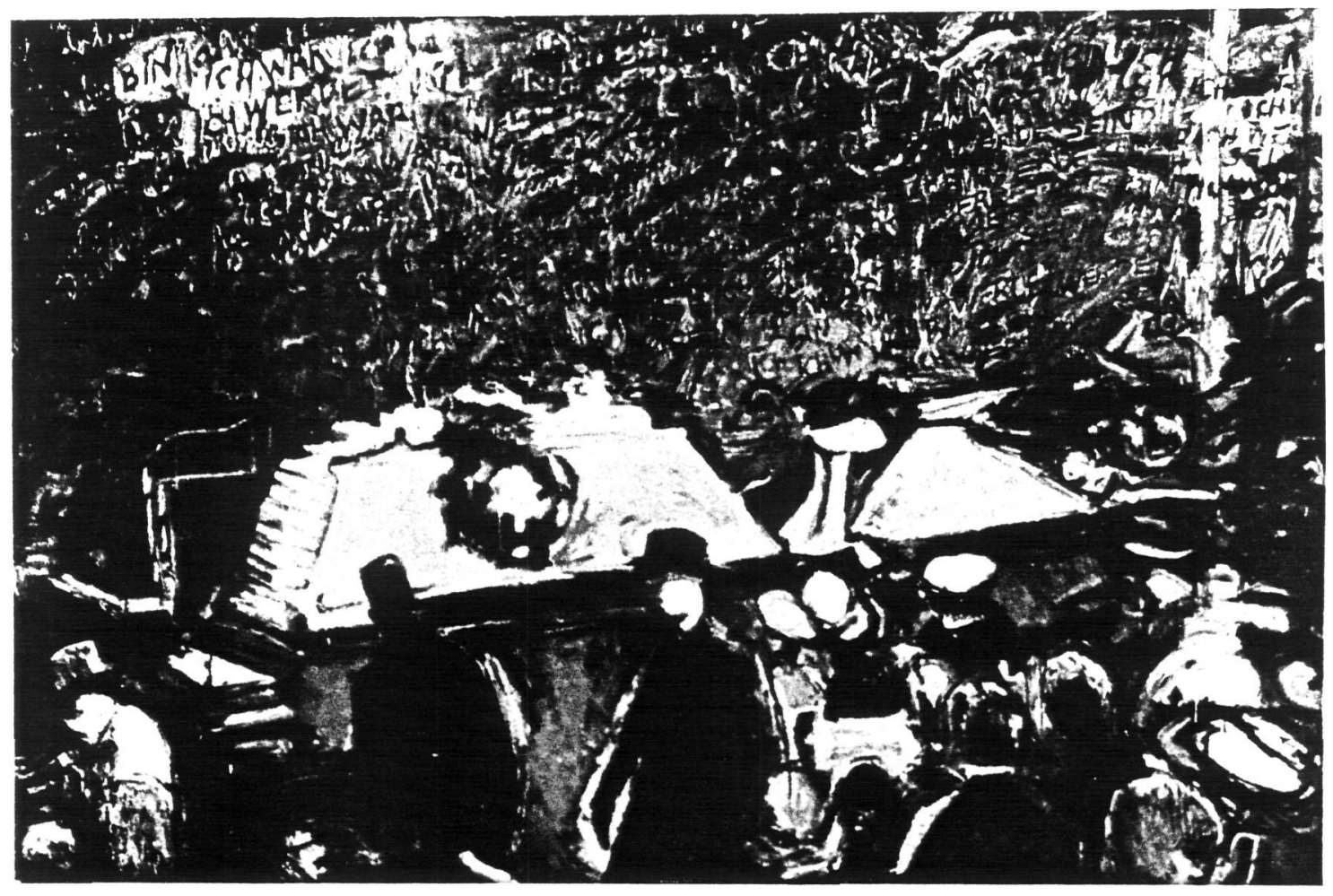

Figure 1. May Stevens, Voices, 1983. Acrylic on canvas, $78 \times 120 "$.

Jacobsen concludes this essay by quoting from a statement by Stevens which accompanied a 1989 installation.

Presence. Absence. Substitution. Proportion. Quota. Power. Powerlessness. One Less. One more or less. Rosa Luxemburg flared across the European dark like a meteor, an aberration. Her murder restores the usual dark. . . . Order is restored. In Berlin. In Chile. In El Salvador.

(1989, p. 185)

The words are fervent in their activist message.

Josephine Withers (1987) writes about Ordinary. Extraordinary from a woman-centered point of view. Her focus is on foremothers for Stevens and, metaphorically, for all women. The series is, she claims, the artist's

Working Papers in Art Education 1989 - 1990 
"exploration of the relationships between herself and Rosa Luxemburg - her adopted 'ideal' mother - and her own mother, Alice Stevens, and ultimately between Rosa Luxemburg and Alice Stevens" (p. 485). Stevens forges these bonds, argues Withers, by recovering the unknown and lost Alice and Rosa to forge contemporary bonds of strength between women. (Recovering and "remembering," as Daly (1978) has termed it, the lives and contributions of women forgotten or lost to our memories is an established project of feminist art historians.) The large white area in the center of the painting, Fore River for example, can be understood as a metaphor for "the river of life and for the birth canal" that "bring[s] Luxemburg's spirit from the realm of history into a more immediately felt present" (p. 492). Stevens is argued to "midwife Alice Stevens's rebirth" (pp. 491-492). The cyclic nature of motherhood also weaves through Withers' interpretation. Stevens rebirths Alice, and rebirths Rosa, giving them voices, an act of a daughter reclaiming her mothers. At the same time, it is a symbolic act of motherhood in the sense that mothers give birth to life and voice. Withers parallels this with the myth of Demeter and Persephone, in reversed form. Persephone/Stevens brings both Demeters (Alice and Rosa) back from death. Both of their lives are presented in extraordinary and ordinary aspects as historically significant. "Naming, marking, and making visible the forgotten are powerful acts. They are also political acts, the foundations upon which any change in the world takes place" (p. 496). Withers projects through this mother-daughter bond a union between all women, "the erasing of class, of differences" (p. 492).

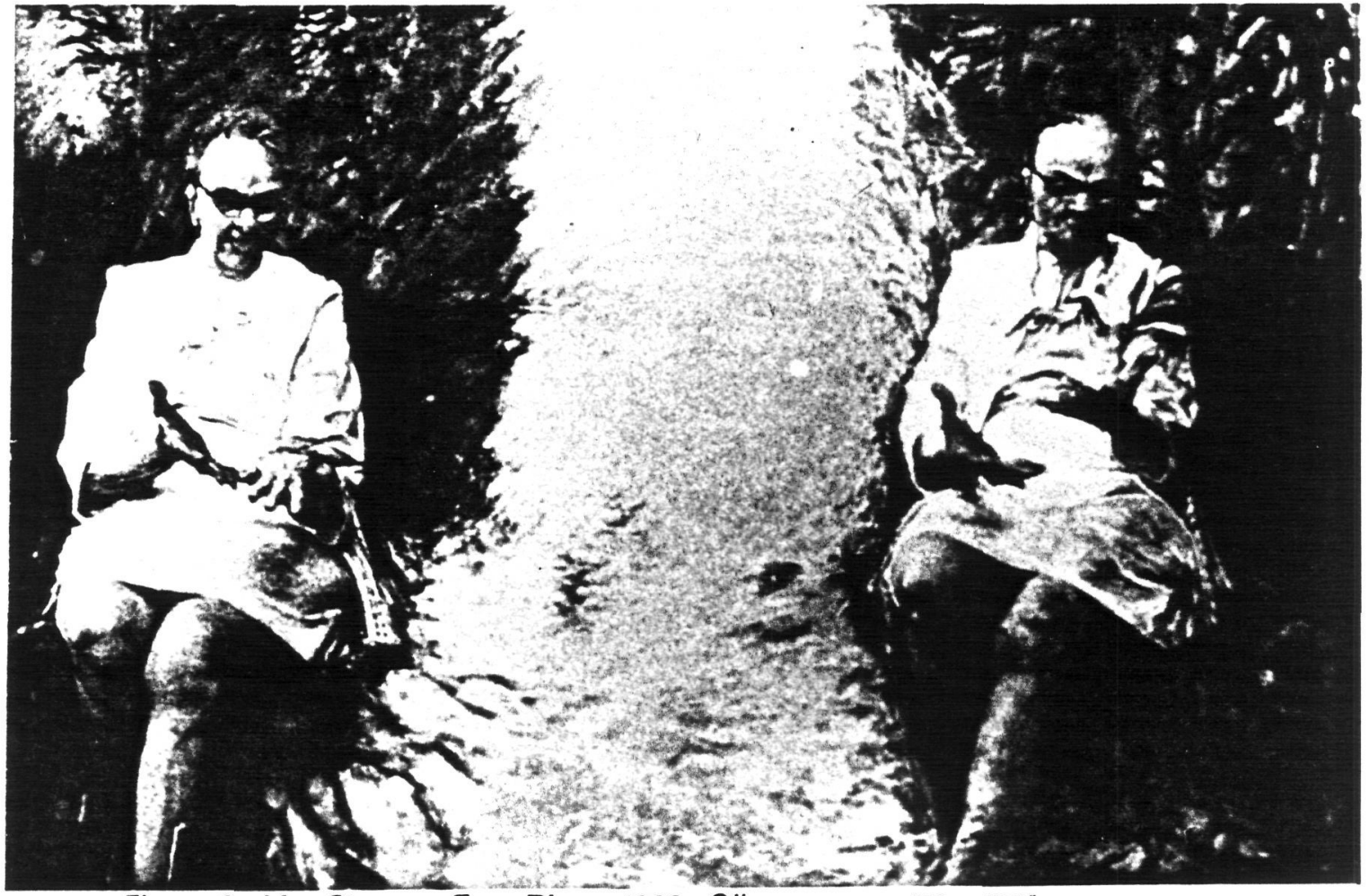

Figure 2. May Stevens, Fore River, 1983. Oil on canvas, 78 x 120". 
Rather than focusing on equal denominators between all women, analytic feminist critic Patricia Mathews (1987) explains the Ordinary.

Extraordinary series as part of a new narrative structure to describe the world and women's experiences in it. She uses Paul Ricoeur's sense of narrative, an "'open interpretive structure"' (cited in Mathews, p. 35). Coherence and continuity of information necessary to orthodox narrative are not elements of the new narrative. Action arises from a dialectic of opposites: "the ordinary and the extraordinary, the personal and political, the marked and the unmarked, the marking and re-marking" (p. 35). In Go Gentle, for example, Mathews perceives "a cinematic sense of climax and resolution" in Alice's lost voice returning as mute gestures. Alice is not telling us anything specific; she is not transferring information. Meaning in her dialogue lies in her inarticulate discourse of gestures. In Go Gentle Alice both sits with hands in lap and gestures wildly. Mathews describes the combination of these states as a narrative sequence that is felt. The various media, sizes, and subjects in the series Mathews argues a product of "discontinuous narrative content as well as signifiers of society's fragmentation" (p.37). Photographs of Alice and Rosa as children in Two Women, for instance, are images of hope; collaged next to images of their agedness and death, they come to mean what has been destroyed as a result of "society's betrayal of women and the elderly" (p. 39). The gap created by the discrepancies of these meanings is the locus for meaning in the new narrative, with multiple texts emerging. The result, argues Mathews, is that a horizontal network of meanings is formed, allowing for representation of the lives of many women.

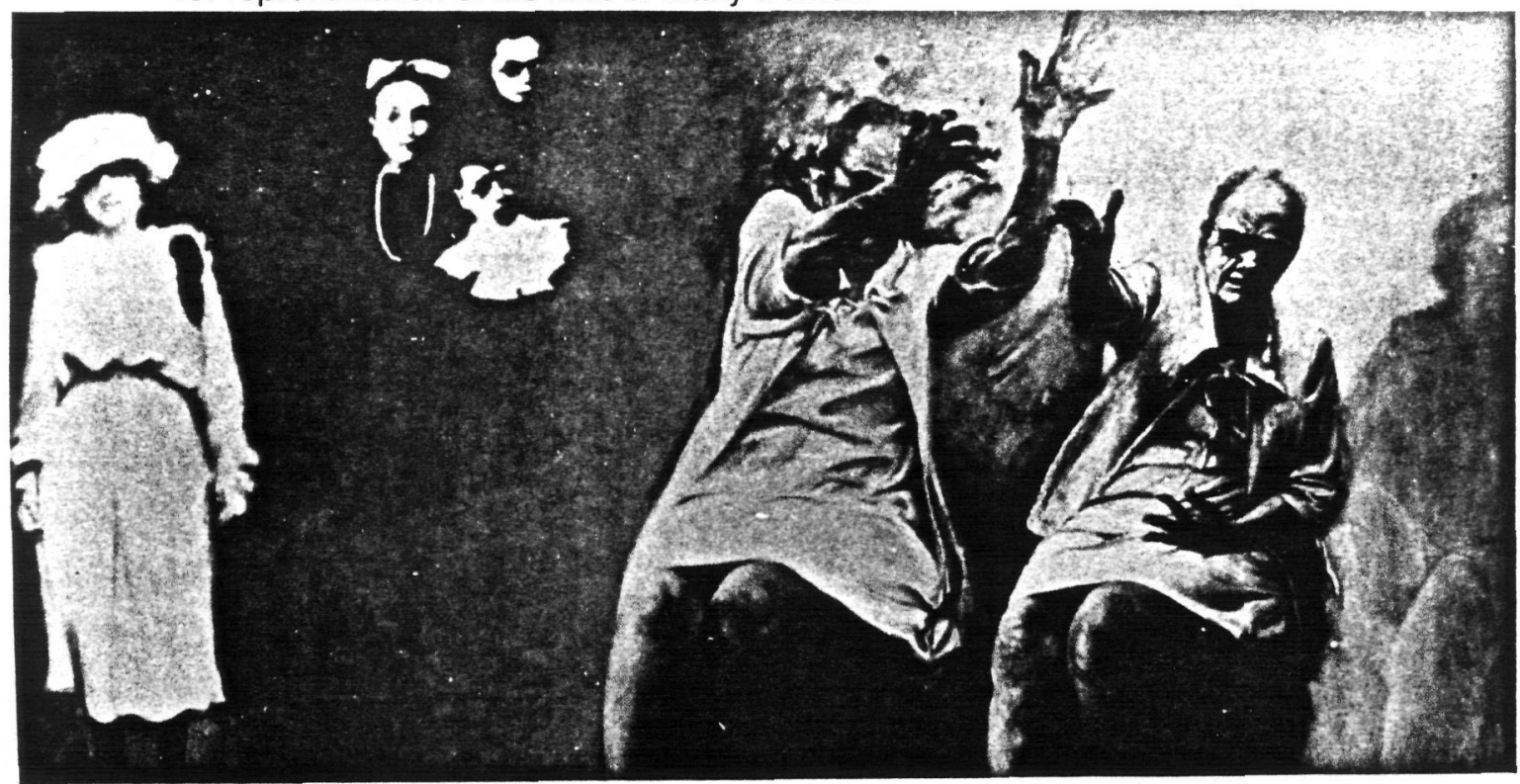

Figure 3. May Stevens, Go Gentle, 1983. Acrylic on canvas, $78 \times 142 *$. 


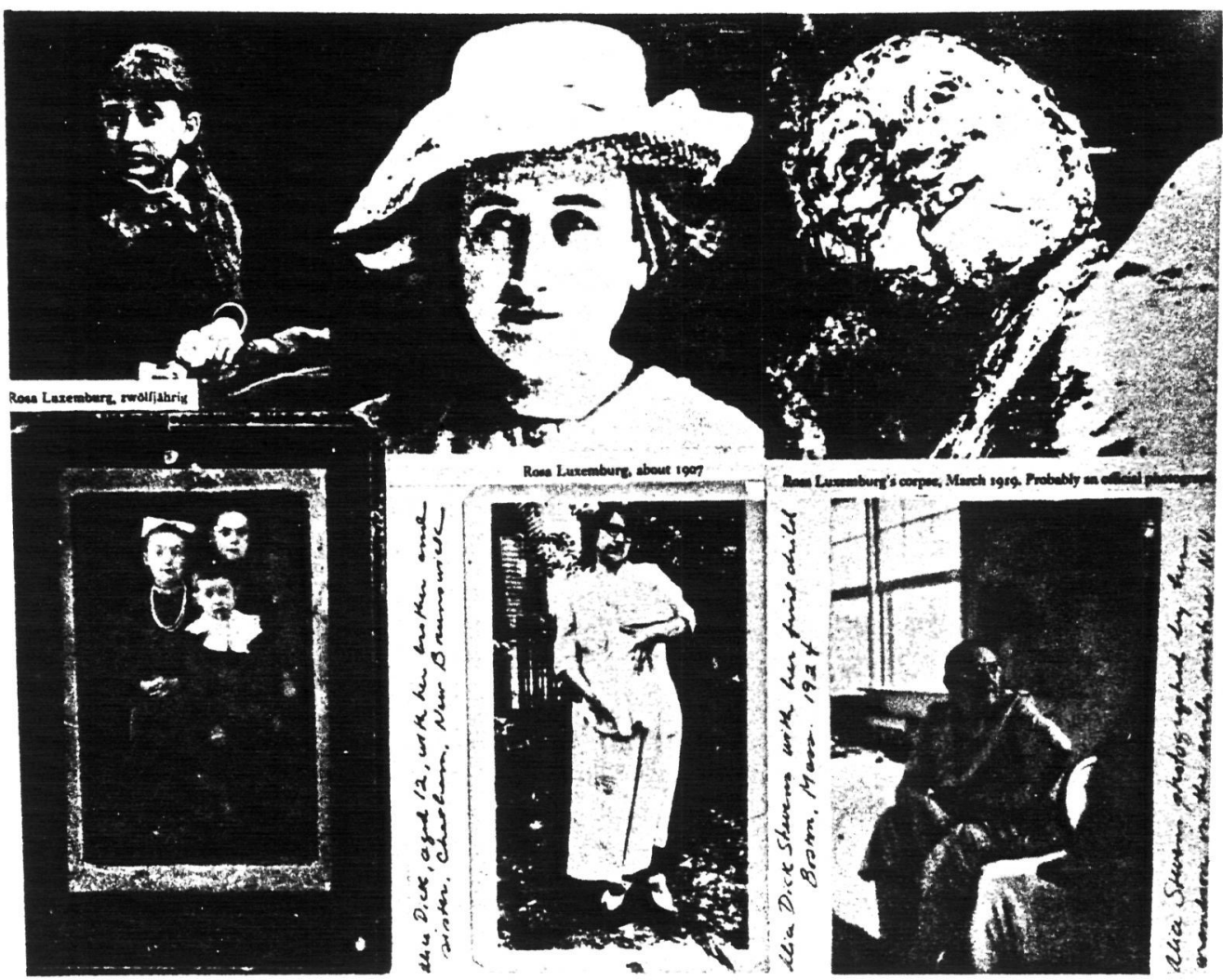

Figure 4. May Stevens, Two Women, 1976. Mixed-media collage, $10.5 \times 13.5^{\prime \prime}$

Mathews' analysis assumed, through the device of narrative, a foundation for meaning in women's lives as socially constructed, with meanings differing because of different social conditions. Withers, on the other hand, implies "supra-historical" (Raven, 1988, p. 16) bonds between all women, and focuses her analysis on the community of all women. Jacobsen's analysis shifts to emphasize the direct political implications of Stevens' work as revolutionary. In studying these interpretations, it is clear that there are irreconcilable differences between Mathews' and Withers' concepts of women. Withers, in emphasizing common denominators and bonding between women implies an essential universal femaleness. Mathews, on the other hand, leaves no possibility of an authentic woman transcendent of culture, since the individual and her story are products of society. These differences characterize, respectively, woman-centered and analytic strands of feminist criticism. Activist feminist critics may embrace either of these concepts, but focus as advocates on political content in art and feminism. 


\section{Conclusion}

Activist, analytic, and woman-centered critiques can be linked to different branches of the feminist movement, and represent particular ideological representations of the world. Through them, we can realize irreconcilable differences as legitimate. Recent scholarship in feminist education is based on the premise that because diverse peoples experience the world variously, "comparative approaches in which each of several perspectives augments and challenges the others" are to be emphasized (Maher \& Rathbone, 1986, p. 216). Maher and Rathbone call for a comparative strategy in presenting information. The three feminist critiques presented here, activist, woman-centered, and analytic, their varying approaches to achieving feminist goals, and their links to different ideological approaches to women signal that instead of looking for a true interpretation, or accepting one based on isolated experience, understanding art can be placed in a context of social and ideological meaning (Nadaner, 1984). Finally, criticism can be understood by students not only as an excavation of meaning, but, as Griselda Pollock (1987) has argued, constitutive of it, as a practice through which particular views - definitions and identities - of the world are constructed and redefined. I believe these comparative and ideological premises should be the focus of teaching art criticism in the schools. Feminist criticism as presented here is an excellent vehicle.

\section{Endnotes}

(1) The marginalization of women from national recognition as artist, for example, was reiterated for me recently when a graduate art student at Penn State, Ellie Reinhold, counted numbers of female to male artists represented in a recent issue of one of the leading two national art publications. She found that over 500 male artists were represented compared to thirty-something female artists.

(2) "Why are there no great women artists?" was republished in 1971 as "Why have there been no great women artists?" In T. B. Hess [Ed.], Art and sexual politics: Women's liberation, women artists, and art history (New York: Collier Books). The article, with the latter title, also appeared in 1971 in Art News, 69 (9).

(3) This model does not include feminist criticism by or about women of color, lesbian women (and there is substantive art and writing by and about both these groups of feminists), nor about non-middle class women, women of various ethnicities or nationalities, and women of differing abilities. It should. I have begun on home territory.

(4) First names will be used when referring to Luxemburg and the Artist's mother because of possible confusion between Alice Stevens and May Stevens. The use of "Stevens," then, will indicate the artist. I do this for clarity, but with hesitation, because so often in art historical and critical writings, 
women artists are referred to by their first names whereas reference to male subjects almost never utilizes this familiar form.

\section{References}

Daly, M. (1978). Gyn/ecology: The metaethics of radical feminism. Boston: Beacon Press.

Garber, E. (1989). Feminist polyphony: A conceptual understanding of feminist art criticism in the 1980s. Unpublished doctoral dissertation, The Ohio State University, Columbus.

Jacobsen, C. (1989). Two lives: Ordinary/Extraordinary. Art in America, 77 (2), 152-156, 183-185.

Kuhn, A. (1982). Women's pictures: Feminism and cinema. London: Routeldge \& Kegan Paul.

Maher, F. \& Rathbone, C. (1986). Teacher education and feminist theory: Some implications for practice. American Journal of Education, 94 (2), 214-235.

Mathews, P. (1987). A dialogue of silence: May Stevens' Ordinary. Extraordinary, 1977-1986, Art Criticism, 3 (2), 34-42.

Nadaner, D. (1984). Critique and intervention: Implications of social theory for art education. Studies in Art Education, 26 (1), 20-26.

Nochlin, L. (1971). Why are there no great women artists? In V. Gornick and B. K. Moran (Eds.), Woman in sexist society: Studies in power and powerlessness, $480-510$.

Pollock, G. (1987). Feminism and modernism. In G. Pollock \& R. Parker (Eds.), Framing feminism: Art and the women's movement 19701985, 79-122. London: Pandora Press.

Raven, A. (1988). Women look at women: Feminist art for the eighties. In Crossing over: Feminism and art of social concern, 13-22. Ann Arbor, MI: UMI Research Press.

Roth, M. (1980). Visions and revisions: Rosa Luxemburg and the Artist's Mother. Artforum, 19 (3), 36-39.

Stevens, M. (1980). Ordinary. Extraordinary. Artist's book. New York: Privately printed. 
Withers, J. (1987). Revisioning our foremothers: Reflections on the ordinary/extraordinary art of May Stevens. Feminist Studies, 13 (3), 485-505. 